Pesq. Vet. Bras. 37(5):531-535, maio 2017 DOI: $10.1590 / \mathrm{S} 0100-736 \mathrm{X} 2017000500018$

\title{
Histological description of Cerdocyon thous (Linnaeus, 1766) respiratory system ${ }^{1}$
}

\author{
Marla P. Rocha ${ }^{2 *}$, Ana Paula Nunes², Luiz Fernando Minello², Luis Augusto X. \\ $\mathrm{Cruz}^{2}$, Ana Paula N. Albano ${ }^{3}$ and Rafael G. Mondadori ${ }^{2}$
}

\begin{abstract}
Rocha M.P., Nunes A.P., Minello L.F., Cruz L.A.X., Albano A.P.N. \& Mondadori R.G. 2017. Histological description of Cerdocyon thous (Linnaeus, 1766) respiratory system. Pesquisa Veterinária Brasileira 37(5):531-535. Faculdade de Medicina, Instituto de Biologia, Departamento de Morfologia, Universidade Federal de Pelotas, Av. Duque de Caxias 250, Fragata, Pelotas, RS 96030-000, Brazil. E-mail: marlapi@yahoo.com.br

The massive agricultural expansion converted the Cerdocyon thous, a South American native predator, in vulnerable specie. Basic data, such as histological description, are important to raise awareness on animal species, helping on preservation strategies. Considering the difficult in obtain samples, as the euthanasia of wild animals for this purpose is not allowed, data on histology are very scarce or inexistent. The objective of this paper was to provide a detailed histological description of the trachea and bronchial tree of the crab-eating fox Cerdocyon thous (Linnaeus, 1766). The specimens (one adult male and one adult female) used were provided by the Federal University of Pelotas (Pelotas, RS, Brazil) Rehabilitation Center of Wild Fauna (NURFS). Tissue samples were fixed in $10 \%$ formalin and included in paraffin. After slicing, samples were stained with HE (hematoxylin and eosin), PAS (periodic acid-Schiff) and resorcin fuchsin. Trachea had an average diameter of $7.87 \mathrm{~mm}$, and approximately $57 \%$ of the mucosa ciliated pseudo-stratified columnar epithelium was composed of goblet cells, mostly in the dorsal region. Bronchia and bronchioles had a mucosal fold with higher number of goblet cells. Using all these techniques there is no great remarkable differences from $C$. thous trachea and lung, when compared with the previous described structures for carnivores and most mammals, except for the goblet cells "regionalization". Described results are important to understand the animal physiological and behavioral habits, allowing the development of preservation and protection strategies.
\end{abstract}

INDEX TERMS: Cerdocyon thous, respiratory system, crab-eating fox, wild canids, histology, trachea, bronchial tree, graxaim.

RESUMO.- [Descrição histológica do sistema respiratório de Cerdocyon thous (Linnaeus, 1766).] A expansão agrícola maciça tornou o Cerdocyon thous, um predador nativo sul-americano, vulnerável. Dados básicos, tais como descrição histológica, são importantes para aumentar o conhecimento sobre as espécies, ajudando nas estratégias de preservação. A eutanásia de animais selvagens para a co-

\footnotetext{
${ }^{1}$ Received on November 16, 2016.

Accepted for publication on December 30, 2016

${ }^{2}$ Departamento de Morfologia, Instituto de Biologia, Faculdade de Medicina, Universidade Federal de Pelotas (UFPel), Av. Duque de Caxias 250, Fragata, Pelotas, RS 96030-000, Brazil. E-mails: anapaula.epi@gmail.com, minellolf@hotmail.com, laugustocruz@gmail.com,rgmondadori@gmail. com; *Corresponding author: marlapi@yahoo.com.br

${ }^{3}$ Hospital Veterinário, UFPel, Av. Duque de Caxias 250, Fragata, Pelotas, RS 96030-000. E-mail: neuschrank@hotmail.com
}

leta de amostras não é permitida, por isso os dados sobre a histologia são muito escassos ou inexistentes. 0 objetivo deste trabalho foi de fornecer uma descrição histológica detalhada da traqueia e árvore brônquica do cachorro do mato Cerdocyon thous (Linnaeus 1766). Os espécimes (um macho e uma fêmea adultos) utilizados foram fornecidos pela Universidade Federal de Pelotas (Pelotas, RS, Brasil), Centro de Reabilitação da Fauna (NURFS). As amostras de tecido foram fixadas em formalina a $10 \%$ e incluídas em parafina. Após o corte, as amostras foram coradas com HE (hematoxilina e eosina), PAS (ácido periódico de Schiff) e resorcina fucsina. A traqueia tinha um diâmetro médio de 7,87 milímetros e aproximadamente $57 \%$ do diâmetro do epitélio colunar pseudo-estratificado ciliado da mucosa composto por células caliciformes, principalmente na região dorsal do órgão. Os brônquios e bronquíolos apresen- 
taram cararísticas similares aos outros animais, contudo aparenta ter maior número de células caliciformes. Usando distintas técnicas de coloração, observou-se que não há diferenças notáveis da traqueia e do pulmão de C. thous quando comparados com os dados para carnívoros e para a maioria dos mamíferos, exceto a regionalização de células caliciformes. Os resultados descritos são importantes para compreender a fisiologia dos animais e hábitos comportamentais, permitindo o desenvolvimento de estratégias de preservação e proteção.

TERMOS DE INDEXAÇÃO: Sistema respiratório, Cerdocyon thous, cachorro do mato, canídeos selvagens, histologia, traqueia, árvore brônquica, graxaim.

\section{INTRODUCTION}

Cerdocyon thous (syn. Dusicyon thous) (Linnaeus, 1766) also known as crab-eating fox, forest fox, wood fox, or graxaim, belongs to the Canidae family and Carnivora order. The species is distributed in South America and is considered native of Argentina, Paraguay, Uruguay, Brazil, Bolivia, Colombia, French Guiana, Suriname and Venezuela (Courtenay et al. 1994). In Rio Grande do Sul state, Brazil, it is the most common wild canid (Silva 1994).

The crab-eating fox has light-gray hair, yellow at the base. Darker hairs on the dorsal line form a black dorsal strip from the neck to the end of the tail. It has predominantly nocturnal habits, feeding on fruits, seeds and small rodents. In livestock farming areas, crab-eating fox is hunted as predator of small domestic animals, mainly lambs. However, there is no scientific evidence of this behavior (Silva 1994), and the reputation of $C$. thous is probably due its opportunistic characteristic. Besides the bad reputation, the species plays an important role in the natural control of rodent populations (Pedó et al. 2006), and contributes to dispersion of native seeds (Albuquerque 2001).

C. thous is graded as less concerning (LC) extinction risk (Beisiegel et al. 2013). Species vulnerability is based on the predator fame, the advancement of agriculture over native biome and death by car hitting. Agricultural expansion reduces the natural diversity of species diet, increasing the contact with farm animals (Nowak 1999). The latter was confirmed by the presence of domestic animals helminth and protozoan parasitizing $C$. thous (Ruas et al. 2008).

The specie-specific basic knowledge, including the macroscopic and microscopic morphology, is important to understand its physiological and behavioral habits, allowing the development of preservation and protection strategies. In addition, morphological characteristics are commonly used to subsidize taxonomic classification (Aversi-Ferreira et al. 2006, Vaz et al. 2011).

Most $C$. thous investigations addresses their eating habits, parasitism, reproductive and behavioral physiology, using captive animals from zoos and reserves (Pimentel et al. 2009, Mattos et al. 2010, Mattoso et al. 2012, Ferreira et al. 2013). Some morphological studies were performed using wild animals died by natural deaths (Lima et al. 2016) or car hitting (Barisson et al. 2012, Souza Junior et al. 2014, Souza Junior et al. 2016) The description of the species' in- ternal morphology demands animal euthanasia, which, by its vulnerability, can only be performed under license from the Brazilian Institute of Environment and Renewable Natural Resources - IBAMA.

As previously stated, the importance of basic knowledge is confirmed by preceding studies that described the morphology of some C. thous systems. Vaz et al. (2011) observed the similarity of the forearm muscles between $C$. thous and Atelocynus microtis, other Brazilian wild canid, as well as between these species and domestic carnivores. The proximity of $C$. thous with domestic dogs was also confirmed by the morphological analysis of bile ducts (Souza et al. 1995) and testicles (Caldeira et al. 2010). On the other hand, Heleno et al. (2011) described peculiar characteristics of the $C$. thous digestive system.

Finally, considering the importance of morphological description of different crab-eating fox systems and the absence of information in this specific field, this paper aims to provide a histologic description of $C$. thous trachea and bronchial tree.

\section{MATERIALS AND METHODS}

The samples used were obtained from one male and one female free-living adults Cerdocyon thous canids. Animals lived on Pelotas municipality, Rio Grande do Sul state, Brazil $\left(31^{\circ} 46^{\prime} 34^{\prime \prime} \mathrm{S}\right.$, $52^{\circ} 21^{\prime} 34^{\prime \prime} \mathrm{W}$ ) and were provided by the Federal University of Pelotas (Pelotas, RS, Brazil) Rehabilitation Center of Wild Fauna (NURFS). This study is part of a project approved in all University instances (code 20402005).

Both animals were admitted to NURFS with history of being hit by a car. Clinical and radiological examinations revealed multiple fractures, including lumbar and thoracic vertebrae, and pulmonary edema. After systematic evaluation and considering the severity of the injuries, veterinarians prescribed and performed the euthanasia of the animals. Just after euthanasia, samples of all organs were collected and fixed in $10 \%$ formalin.

After fixation, trachea and bronchial tree fragments were dehydrated in increasing concentrations of ethyl alcohol, clarified with xylene and included in paraffin. The paraffin blocks were sliced $(7 \mu \mathrm{m})$ on a semi-motorized rotatory microtome (Leica RM2245 ${ }^{\circledR}$ ) and collected in slides. Tissue samples from each part of the organs were dyed with four techniques: HE (hematoxylin and eosin), PAS (periodic acid-Schiff) and resorcin fuchsin. Slides were evaluated under an optical microscope (Nikon Eclipse E200 ${ }^{\circledR}$ ) coupled with a camera (Moticam $5^{\circledR}$ ), and the images were captured using the Motic ${ }^{\circledR}$ Image Plus 2.0 and measured using Image Pro Plus 2.0 software.

\section{RESULTS}

Cerdocyon thous trachea had an average diameter of $7.87 \mathrm{~mm}$, ranging from 8.05 to $7.7 \mathrm{~mm}$. The wall is formed by the mucosa, sub-mucosa, cartilaginous and adventitia layers (Fig.1).

The mucosa layer is formed by ciliated pseudo-stratified columnar epithelium with goblet cells. The PAS staining revealed goblet cells distributed preferably in the trachea's dorsal region, corresponding to approximately $57 \%$ of the diameter (Fig.1A and 1B).

The lamina propria of this organ is predominantly formed by loose connective tissue, becoming more fibrous toward the sub-mucosa. The mucosa and sub-mucosa layers 


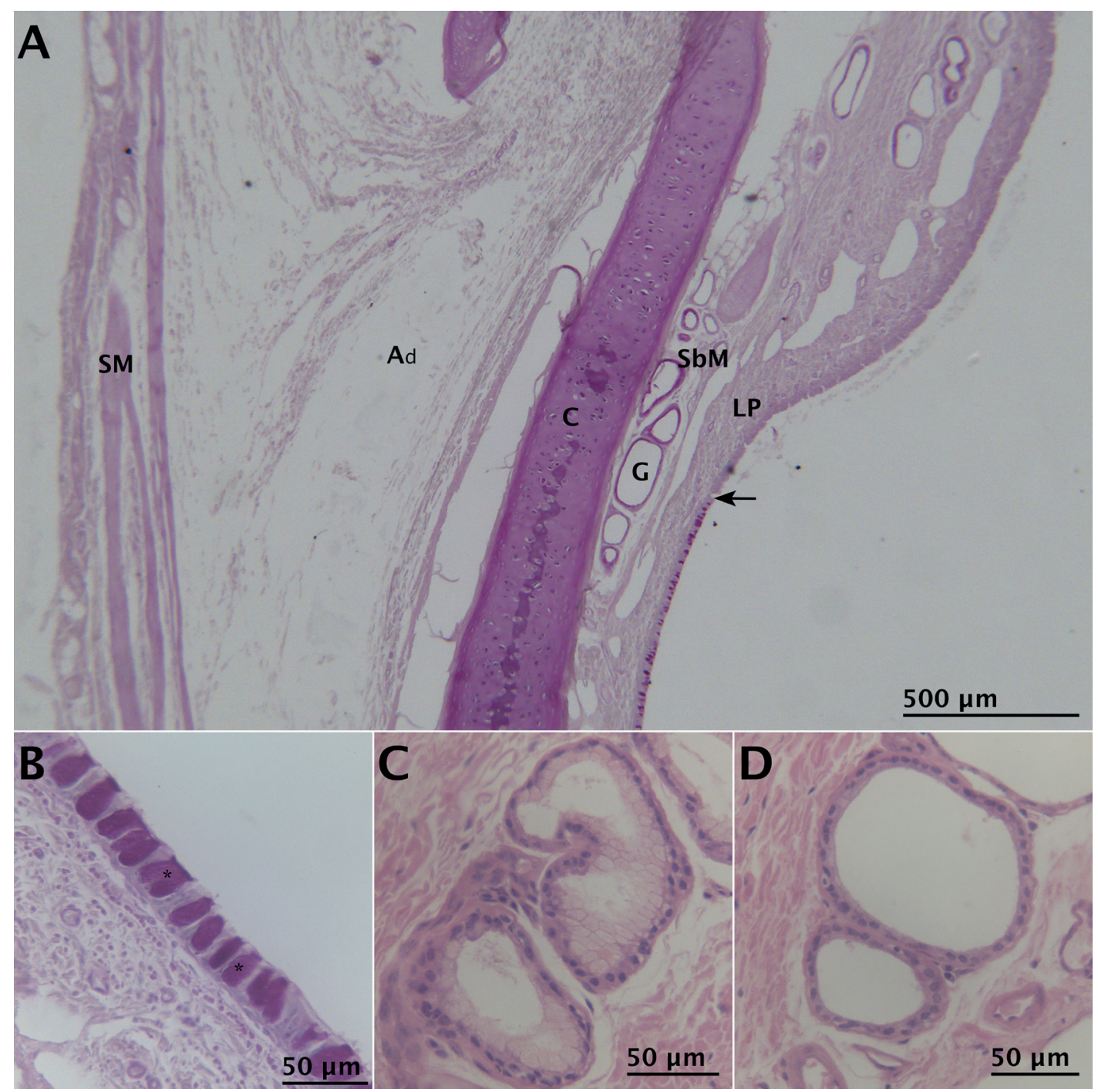

Fig.1. Cerdocyon thous trachea. (A) Arrow indicates the point where goblet cells disappear from the epithelium. Note the presence of the loose connective tissue lamina propria (LP), the sub-mucosa (SbM) with glands (G), the adventitia (Ad) and the smooth muscle (SM) that forms a belt around hyaline cartilage (C) piece. (B) Sequence of goblet cells $\left({ }^{*}\right)$ in the respiratory epithelium. (C) Sub-mucosa mucous glands. (D) Sub-mucosa serous glands. PAS (A and B) and HE (C and D) staining.

vary in thickness, wherein the thicker portion measured $0.45 \mathrm{~mm}$ and the thinner $0.23 \mathrm{~mm}$. Embedded in sub-mucosa it was possible to observe predominantly mucous (Fig.1C) and also serous (Fig.1D) tubular glands.

Tracheal sub-mucosa is continuous with the connective tissue that surrounds the piece of hyaline cartilage, which has a horseshoe shape with a dorsal open, as observed in most mammals. At the dorsal open it was possible to observe the presence of smooth muscle (tracheal muscle) forming a belt (Fig.1A). Cartilage thickening ranged from $0.85 \mathrm{~mm}$, at the central portion, to $0.12 \mathrm{~mm}$ at the ends of the piece. As can be observed in Figure $1 \mathrm{~A}$ and Figure 2 , tracheal adventitia was composed of loose connective tissue with unilocular fat cells, traversed by branches of the vagus nerve.

Lungs were externally covered by visceral pleura formed by mesothelium and underlying loose connective tissue containing blood capillaries. The organ parenchyma had a spongy aspect due to the presence of alveoli, alveolar ducts, alveolar sacs, bronchioles, bronchi and blood vessels with different calibers (Fig.3).

Bronchial mucosa and sub-mucosa presented helical bundles of smooth muscles among loose connective tissue. Loose connective tissue became gradually dense irregular toward the hyaline cartilage islands, with circular fibers.

Predominantly serous tubular glands, with simple cubic secretor epithelia, were observed in the lamina propria. In the same connective tissue it was also possible to observe medium caliber blood vessels and capillaries, and transversal and longitudinal orientated nerves. Bronchia hyaline cartilage islands, which correspond to remnants of trachea fibro-cartilaginous layer, were coated with a thick acidophilus perichondrium. A thin adventitia composed by loose connective tissue continuous with adjacent structures was observed (Fig.4).

The bronchiolar lumen is lined by ciliated pseudo-stratified columnar epithelium with goblet cells changing to simple cubic in the transitional portion. The lami- 


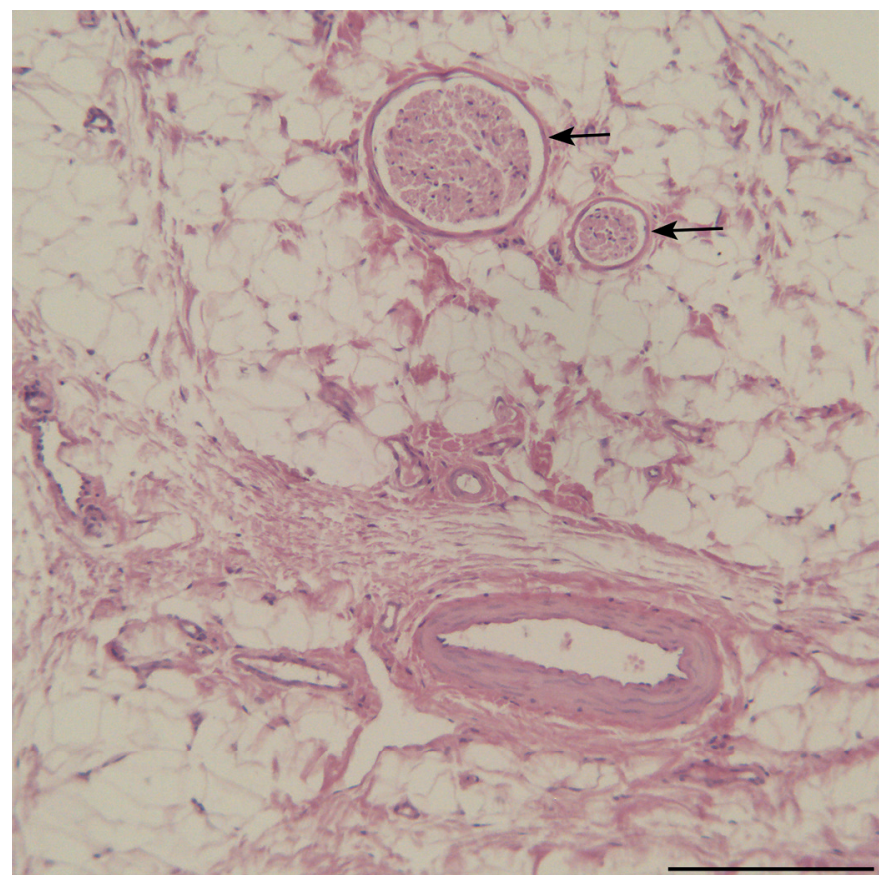

Fig.2. Vagus nerve branches (arrows) in Cerdocyon thous trachea adventitia. HE staining. Scale bar $200 \mu \mathrm{m}$.

na propria/sub-mucosa was predominantly formed by connective tissue, containing bundles of smooth muscle and helicoid elastic fibers. Adventitia was adjoined to the adjacent connective tissue (Fig.5A). It was also observed smaller bronchioles with cylindrical, cubic and squamous epithelia, indicating the transition from terminal to respiratory bronchiole. Goblet cells and cilia were not visible in respiratory bronchioles, alveolar ducts with club (Clara) cells (Irwing et al. 2013), sporadically interrupted the wall. Both lamina propria and the muscle layer were decreasing as bronchioles progress from terminal to respiratory. The adventitia was thin and continuous with the surrounding tissues (Fig.5B).

The alveoli were lined by single squamous epithelium which were linked directly to a blood capillary endothelium or loose connective tissue with capillaries, demons-

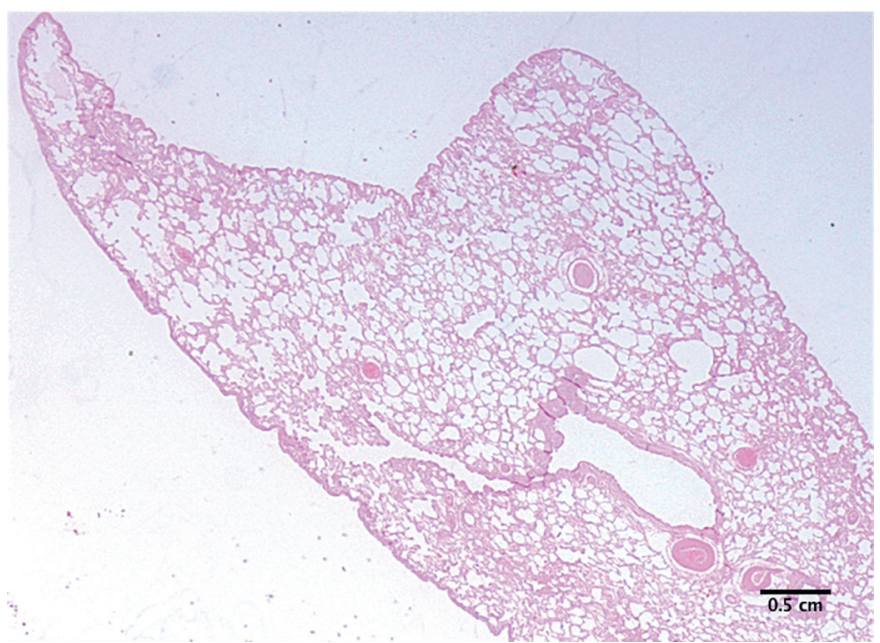

Fig.3. Cerdocyon thous lung. Note the spongy aspect due the presence of different diameters alveoli. HE staining.

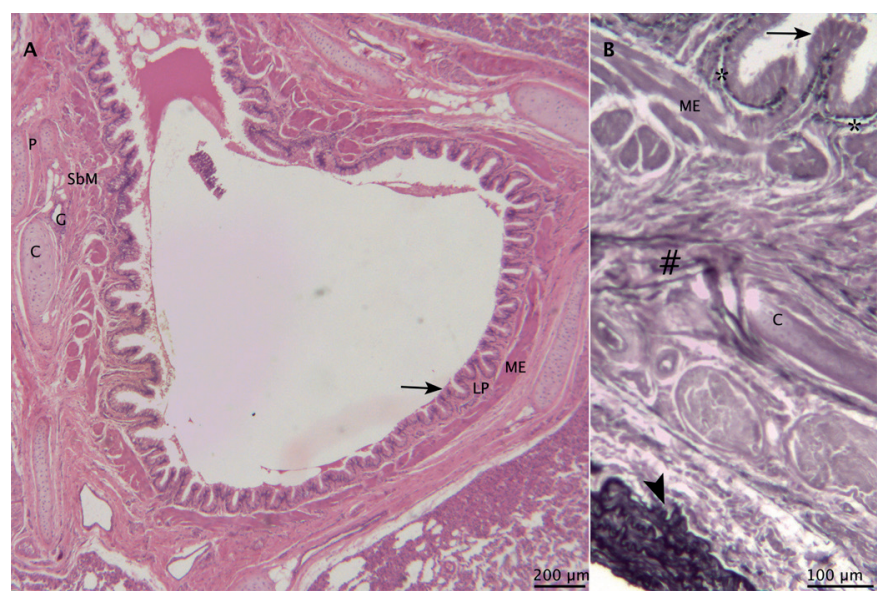

Fig.4. Cerdocyon thous bronchus. The organ's wall is formed by respiratory epithelium (arrow), lamina propria (LP), muscleelastic layer (ME), sub-mucosa (SbM) with glands $(G)$ and hyaline cartilage (C) with perichondrium (P). In B, elastic elements can be observed in the limit between bronchial mucosae and sub-mucosa $(*)$, in the smooth muscle connecting cartilage pieces (\#) and in the artery wall (arrow head). HE (A) and resorcin fuchsin (B) staining.
Fig.5. (A) Cerdocyon thous terminal and (B) respiratory bronchioles. Wall is formed by epithelia (arrow), lamina propria (LP) and smooth muscle (M). HE staining. Scale bar $100 \mu \mathrm{m}$.
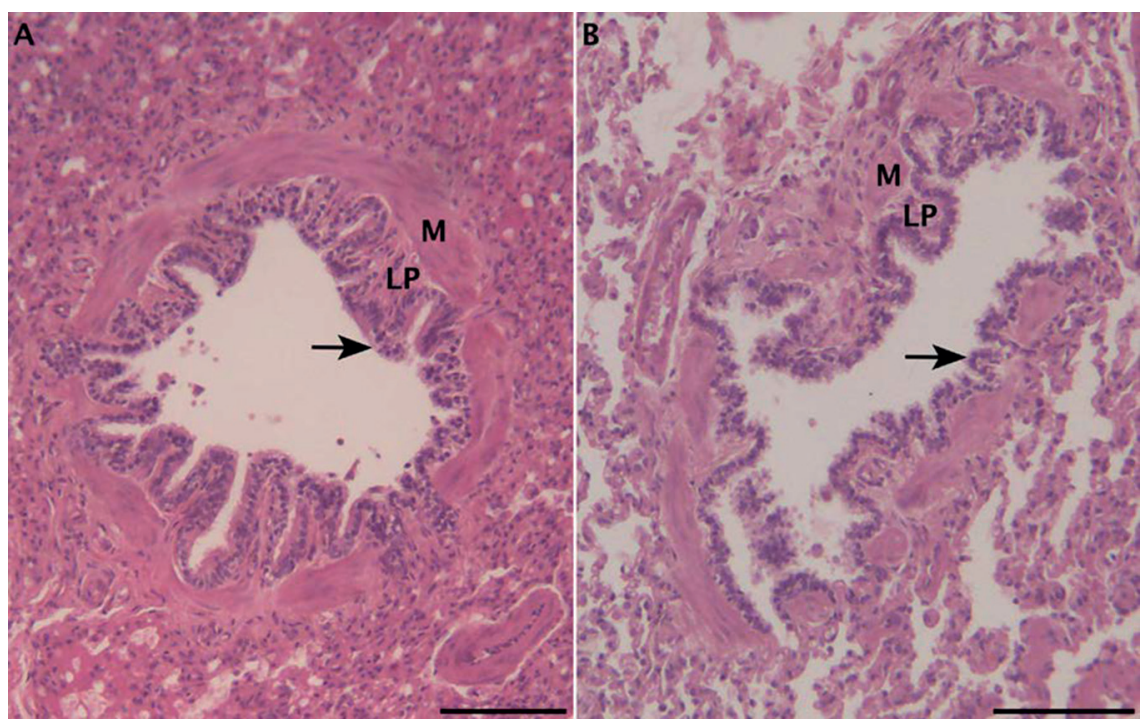
trating the blood-air barrier variation, thinner and more functional or thicker and less functional, respectively. In the connective alveolar septa, fibroblasts and few resident macrophages were observed.

Near the alveoli it was possible to observe the cushions, connective tissue with few smooth muscle cells surrounded by simple cubic epithelia, which represent the passage of an alveolar duct. Alveolar ducts delimit the alveolar sacs, a dead space area before the alveoli, which does not present a morphological identity, such as ducts and alveoli.

\section{DISCUSSION}

As previously described for the laryngeal morphology (Souza Junior et al. 2016), trachea and bronchial tree are also similar between crab-eating fox and other canids. Cerdocyon thous trachea has the same layers found in most animals. In general, mucosal epithelium is similar, except that, different from other species where they are homogeneously distributed between the lining cells, in C. thous trachea they are preferably in the dorsal region, corresponding to approximately $57 \%$ of the inner diameter. This suggests the occurrence of regionalization of goblets cells, described in carnivores by Samuelson (2007), indicating the maintenance of a "trails" distribution in crab-eating fox. This regionalization seems not to be present in the red fox (Vulpes vulpes) trachea (Moussa \& Hassan 2015). Another specific carnivore characteristic present in $C$. thous trachea is the smooth muscle belt around hyaline cartilage piece, rather than internally located smooth muscle (tracheal muscle) present in humans.

As previously stated, $C$. thous lung histological pattern is similar most animals and wild canids (Paranaíba et al. 2016). Despite there is no remarkable histological differences between the crab-eating fox trachea and the bronchial tree with other animal species, these results are important to understand the animal physiological and behavioral habits, allowing the development of preservation and protection strategies.

\section{CONCLUSION}

This paper provided histologic and morphometric data of Cerdocyon thous trachea and bronchial tree, allowing comparision with other species. $C$. thous respiratory system is histologically similar to other canids.

\section{REFERENCES}

Albuquerque L.B. 2001. Polinização e dispersão de sementes de solanáceas neotropicais. Dissertation, Instituto de Biologia, Unicamp, Campinas.

Aversi-Ferreira T.A., Vieira L.G., Pires R.M., Silva Z. \& Penha-Silva N. 2006. Estudo anatômico dos músculos flexores superficiais do antebraço no macaco Cebus apella. Biosci J. 22:139-144.

Barisson J.D., Louro C.H., Dias S.J.T., Jojima F.S., Ferreira M.S. \& Oliveira F.S. 2012. Anatomo-radiographic description of the axial skeleton of the crab-eating fox (Cerdocyon thous). Pesq. Vet. Bras. 32(Supl.1):1-3.

Beisiegel B.M., Lemos F.G., de Azevedo F.C., Queirolo D. \& Jorge R.S.P. 2013. Avaliação do risco de extinção do Cachorro-do-mato Cerdocyon thous (Linnaeus, 1766) no Brasil. Biod. Bras. 3(1):138-145.

Caldeira B.C., Paula T.A.R., Matta S.L.P., Balarini M.K. \& Campos P.K.A. 2010
Morphometry of testis and seminiferous tubules of the adult crab-eating fox (Cerdocyon thous, Linnaeus, 1766). Ceres 57(5):569-575.

Courtenay O., MacDonald D.W., Lainson R., Shaw J.J. \& Dye C. 1994. Epidemiology of canine leishmaniasis: a comparative serological study of dogs and foxes in Amazon Brazil. Parasitology 109(3):273-279.

Ferreira P.R.B., Larangeira D.F., Oliveira L.S., Malta M.C.C., Gomes M.C., Bastos B.L., Portela R.W.D. \& Barrouin-Melo S.M. 2013. Indirect ELISA for the serological diagnosis of visceral leishmaniasis in wild canids. Pesq. Vet. Bras. 33(4):528-534.

Pedó E., Tomazzoni A.C., Hartz S.M. \& Christoff A.U. 2006. Diet of crab-eating fox, Cerdocyon thous (Linnaeus) (Carnivora, Canidae), in a suburban area of southern Brazil. Revta Bras. Zool. 23:637-641.

Heleno A.R., Santos L.M., Miglinno M.A., Peres J.A. \& Guerra R.R. 2011 Biometria, histologia e morfometria do sistema digestório do cachorro-do-mato (Cerdocyon thous) de vida livre. Biotemas 24(4):111-119.

Irwin R.S., Augustyn N., French C.T., Rice J., Tedeschi V. \& Welch S.J. 2013. Spread the word about the journal in 2013: from citation manipulation to invalidation of patient-reported outcomes measures to renaming the Clara cell to new journal features. Chest 143(1):1-5.

Lima A.R., Souza D.C., Carmo D.C., Santos J.T. \& Branco E. 2016. Ramos colaterais do arco aórtico e suas principais ramificações no cachorro-do-mato (Cerdocyon thous). Pesq. Vet. Bras. 36(7):647-651.

Mattos M.R.F., Simões-Mattos L., Pilati C., Silva L.D.M. \& Domingues S.F.S. 2010. Intersexuality in a crab-eating fox (Cerdocyon thous). Pesq. Vet. Bras. 30(6):510-514.

Mattoso C.R.S., Catenacci L.S., Beier S.L., Lopes R.S. \& Takahira R.K. 2012. Hematologic, serum biochemistry and urinary values for captive Crab-eating Fox (Cerdocyon thous) in São Paulo state, Brazil. Pesq. Vet. Bras. 32(6):559-566.

Moussa E.A. \& Hassan S.A. 2015. Histology and Scanning Electron Microscopy of the Lower Respiratory Tract in the Adult Red Fox (Vulpes vulpes). Int. J. Morphol. 33(1):267-274.

Nowak R.M. 1999. Walker's mammals of the world. John Hopkins 6th ed. University Press, Baltimore, Maryland. 2015p.

Paranaíba J.F.F.S., Lima F.C., Pereira D.K.S., Araújo E.G. \& Pereira K.F. 2016. Morfo-histologia dos pulmões e árvore bronquial de Procyon cancrivorus (Carnivora: Procyonidae). Arq. Bras. Med. Vet. Zootec. 68(2):353360.

Pimentel J.S., Gennari S.M., Dubey J.P., Marvulo M.F.V., Vasconcellos S.A., Morais Z.M., Silva J.C.R. \& Evêncio Neto J. 2009. Serological survey of toxoplasmosis and leptospirosis in neotropical wild mammals from Aracaju Zoo, Sergipe, Brazil. Pesq. Vet. Bras. 29(12):1009-1014.

Ruas J.L., Muller G., Farias N.A., Gallina T., Lucas A.S., Papen F.G., Sinkoc A.L. \& Brum J.G. 2008. Helminths of Pampas fox, Pseudalopex gymnocercus (Fischer, 1814) and of craba-eating fox, Cerdocyon thous (Linnaeus, 1766) in the South of the State of Rio Grande do Sul, Brazil. Revta Bras. Parasitol. Vet. 17(2):87-92.

Samuelson D.A. 2007. Tratado de Histologia Veterinária. Elsevier, Rio de Janeiro. 527p.

Silva F. 1994. Mamíferos silvestres, Rio Grande do Sul. 2014. Fundação Zoobotânica do Rio Grande do Sul. 244p.

Souza Junior P., Carvalho N.C., Mattos K. \& Santos A.L.Q. 2014. Origins and ramifications of brachial plexus in the crab-eating-fox Cerdocyon thous (Linnaeus, 1766). Pesq. Vet. Bras. 34(10):1011-1023.

Souza Junior P., Carvalho N.C., Mattos K., Anjos L.A. \& Santos A.L.Q. 2016. Morfologia da laringe em Cerdocyon thous (Linnaeus, 1766). Pesq. Vet. Bras. 36(1):45-54.

Souza W.M., Miglino M.A., Custódio A.A. \& Didio L.J.A. 1995. The distribution of the biliary ducts in wolves (Cerdocyon thous and Chrysocyon brachyurus). Braz. J. Morphol. Sci. 12(2):95-99.

Vaz M.G.R.L., Lim A., Souza A.C.B., Pereira L.C. \& Branco E. 2011. Estudo morfológico dos músculos do antebraço de cachorro-do-mato-de-orelhas-curtas (Atelocynus microtis) e cachorro-do-mato (Cerdocyon thous). Biotemas 24(4):121-127. 